\title{
Planning Special Events ${ }^{1}$
}

\author{
Reba Ellen Hicks, Ricky Telg, and Tracy Irani ${ }^{2}$
}

This publication on planning special events is the first of a two-part series regarding the planning of special events. The other publication in this series focuses on marketing and public relations related to event planning.

\section{Introduction}

If you have ever planned a meeting, put together a party for someone, worked on a fundraiser for a nonprofit organization or organized a bazaar at your church or school, you have experienced planning a special event. A special event is a planned gathering of people who get together to engage in some shared activity. Whether it is a potluck supper shared by neighbors or a national conference with hundreds or thousands of attendees, special events do not just "happen." Events are special occasions that need to be planned in order to be successful. Planning an event takes special skills in communication, organization of details, creativity, negotiation, teamwork, and leadership. Learning how to plan special events is an important skill that can benefit you and your organization.

This publication is designed to help you understand what special events are and how to conduct them. After reading this publication, you will be able to explain how event sites are chosen, what criteria are used to plan events, and how to handle site permits, contracts, and budgets. You also will learn the five critical stages in planning a special event and how to evaluate an event.

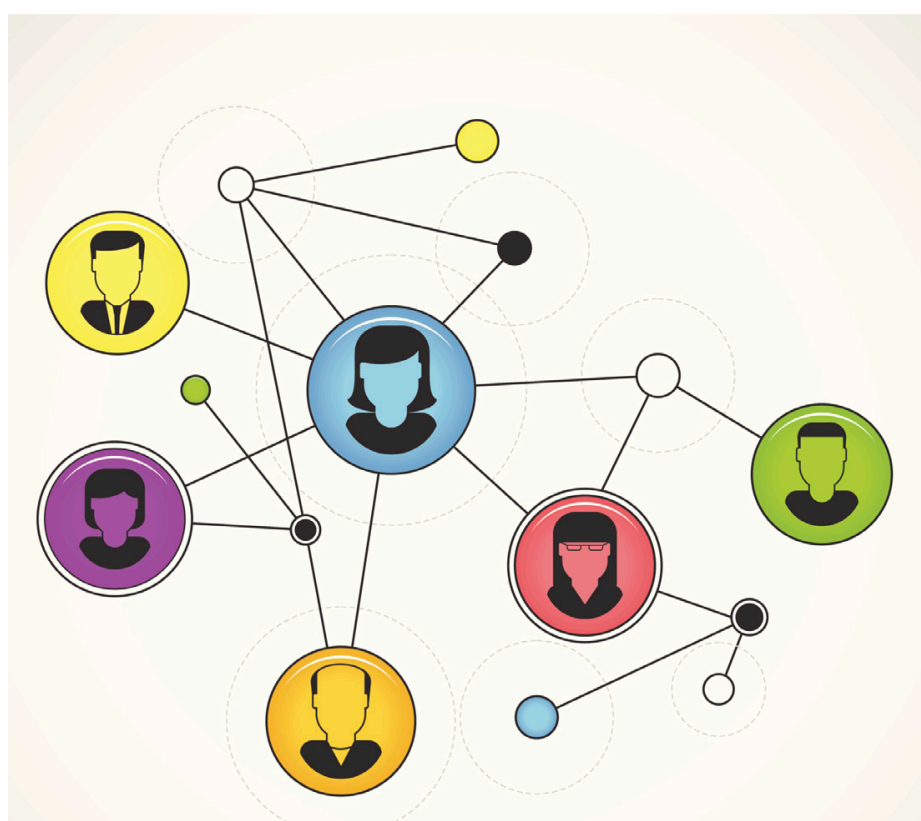

\section{Making an Event "Special"}

Special events can range from a small meeting or get together of members of a group or organization, to large-scale conventions, concerts, and parades. The people responsible for organizing and conducting a special event have become known as event managers. Event managers create, design, plan, coordinate, and manage events of all types. To be successful, an event manager needs to be a person of vision and have a great deal of initiative, energy, and dedication. As managers, all elements of the event are their responsibility, so event managers must be good leaders and team members, capable of inspiring others to do the best job they can. Event managers must be able to

1. This document is AEC484 (formerly WC147), one of a series of the Agricultural Education and Communication Department, UF/IFAS Extension. Original publication date July 2013. Visit the EDIS website at http://edis.ifas.ufl.edu.

2. Reba Ellen Hicks, graduate student; Ricky Telg, professor; and Tracy Irani, professor, Agricultural Education and Communication Department, UF/IFAS Extension, Gainesville, FL 32611. 
communicate effectively with a diverse range of people and personalities. They also need to be organized and able to take on a variety of roles, as well as be cool under pressure.

\section{Stages of a Special Event}

Imagine you are the event planner for a fundraising event. To keep the event on track so that it runs smoothly requires lots of preparation. Successful events are those that are produced in the following stages:

- Planning the event: At the start, you must determine your objectives, identify your audience, and conduct research to determine if the event is viable.

- Event logistics: In this stage, you work on putting these elements in place, often with a team of other people who are responsible for specific tasks.

- Event-day coordination: On the day of the event, you coordinate all the details and the people working on the event with you.

- Event evaluation: At the end of the event, you wrap up and evaluate how it went, making sure to note ideas for improvement in the future.

\section{Planning the Event}

All successful events start with a plan. A special event is an organized activity, incorporating many elements, so a plan helps you stay organized and includes all the details necessary to make your event a success. The elements that go into a plan for a special event of any type include determining your objectives, identifying your audience, and conducting research.

\section{OBJECTIVES}

To have a successful event, you need to balance the needs of your audience with your objectives for the event. Do you primarily want to raise funds for a project? Do you want to make members of your community more aware of what goes on with a particular extension program? The answers to these questions will tell you who your primary audience is, and that will help you decide what kind of event you want to have. Your objectives should be measurable - for example, raising $\$ 15,000$ at an event. In your evaluation, you can then see how much money you raised, indicating if you met your measurable objective.

\section{AUDIENCE}

Sometimes your audience will consist of more than one group, but there should be a primary audience that you want to build the event around. A school carnival, a banquet, or a festival might attract several different audiences.
The type of activities you plan will depend on which audience you are trying to reach.

\section{RESEARCH}

Doing some research before you plan and select the elements of an event helps you avoid and reduce risks. Having people not come to an event that you have spent a lot of time and money to develop is a big risk. Primary research, such as talking to people who might come to a meeting to find out the best day and time for them or sending out a survey in the case of a large event, are forms of research you can do before planning begins. Secondary research, which involves reviewing published sources of information, is also helpful. Looking up the dates for potentially conflicting organizational activities on a calendar or on a website is a form of secondary research.

Benchmarking is a special kind of research that involves looking at what other organizations have done to plan events similar to yours. You might be able to get ideas from benchmarking other organizations' events, and you might also be able to find out how things went, so you can avoid things that did not go well and perhaps adopt elements that did go well for your own event.

\section{Logistics}

Logistics refers to working out everything involved in selecting and developing the right type of event to achieve your objectives. Even if you are organizing a simple meeting, the selection of the location, timing and date, speakers, and activities are all crucial decisions that influence the ultimate outcome. Some general logistic considerations are listed below.

\section{FOOD AND ENTERTAINMENT}

Food is one of the biggest costs budgeted for an event. If there is going to be food, how much will there be and what type: finger foods, buffet, or a sit-down meal? If you have enough money budgeted - as you might for a wedding or a conference - you might be able to work with a caterer. Otherwise, you might need to consider having a "potluck," where attendees or members all bring a food dish. Your organization might contribute the main dish, to make sure there will be enough food to go around. Keep in mind that some event sites only allow you to use a particular caterer or to select from a small number of caterers. Dietary concerns are a consideration for many events now; for example, you may want to have vegetarian options for people who attend the event. 
Entertainment can range from background music playing on a computer with speakers to full-scale entertainment on a stage with performers or a speaker. Entertainment can also take the form of games and activities for attendees, which can be informal or very organized. It is important to match the entertainment to the audience, and to the time allotted for the event. Even the most interesting of speakers, if he or she goes on too long, can cause the audience to tune out and be bored.

\section{THEME AND DECORATIONS}

Events often have themes to make it easier to decorate the site location and promote the event. Good themes add to participants' enjoyment and memories of the event. Coming up with an effective theme takes some thought. Themes should be simple, relate to the event, and be visually appealing. All print and other promotional materials such as tickets, posters, and fliers should be designed around the event theme. All decorations - including costumes, props, sets and signs - also should be consistent with the theme in some way, such as the use of the theme as a logo or the use of consistent colors.

\section{DATE AND TIME}

The main elements of the event must be communicated to attendees as well as those who will be helping out, so the date and time must be set early. It is important to think through the best time to hold your event, so that there are not any conflicts with other events that might attract the same audience. Are there any dates that will not work because of a conflict, or because they're too near a holiday or vacation period? If many in your audience could be expected to attend or watch another event, they will be unlikely to go to your event. Get out the calendar and cross out dates and times that do not work before picking some that do. Check the date, and times with a few people who might be attending before committing to the date.

\section{LOCATION}

Picking a good location involves knowing the size of your potential audience, and then scouting potential locations to make sure they can accommodate the number of people you are expecting. If you have ever been in an overcrowded meeting room, you know how quickly overcrowding can influence your appreciation of the event you are attending. Always allow for a few more people than you expect to come, just in case more show up. This is also a good policy when figuring out how much food to serve. Caterers will usually add a few more "places" than what was ordered for this reason. Running out of food can be as bad as not having enough room.
To work out how much room you might need, you might consider using a site diagram. Site diagrams are sketches of the facility, usually with dimensions included. Items you should sketch into your site diagram would include tables, chairs, audio-visuals, stage/podium, entrance/exit, decorations, displays/exhibits, and trash. Once you have made your site diagram, you can estimate how much room there will be available for attendees.

\section{SPONSORSHIP}

Getting sponsors to financially support your event is a way of ensuring that you do not lose money. It is also a way of developing linkages and adding to the credibility of your goals. Sponsorship is extremely time-consuming. It is not the same as a goodwill donation, where donors contribute without any expectation of commercial benefit. Sponsorship is a commercial transaction, and sponsors want to see a return on their investment (ROI). For example, they may see that participating in a special event that targets their customers may be a way of generating positive publicity and favorable consumer attitudes. In an indirect way, such a sponsorship may even help drive sales if attendees at the special event recognize the sponsor and subsequently patronize their company. Many sponsors want the event manager to help them measure their ROI. Some broad objectives companies use to determine sponsorships include the following:

- Enhance image and consumer attitudes about the company

- Drive sales

- Obtain positive publicity and visibility

- Promote goodwill because it positions the sponsor as a community "good citizen"

- Contribute to community development

Some examples of special events and prospective sponsors include:

- Fairs: soft drink distributors, grocers, automotive dealers, banks

- Festivals: department stores, music stores

- Sports: athletic wear, soft drink distributors, hospitals

- School programs: children's toy stores, children's clothing stores, amusement parks

- Meetings/conferences: banks, commercial printers, insurance brokers

There are several types of sponsorships that can be used for a special event or activity. A title sponsor pays a premium 
fee to have their name become a part of the event itself. An event can have more than one sponsor, called co-sponsorship, where more than one organization shares sponsorship of the event. An exclusive sponsor is one who pays extra to be the only sponsor of the event. If the sponsor is a media outlet, like a local newspaper or radio station, the media sponsor may not provide funds, but often does provide a predetermined amount of advertising for the event. In-kind sponsors do not financially support an event, but they do donate products or services. For example, a school club may decide to have a plant sale to raise funds for a trip. If club members were able to get the plants donated by a local nursery, the nursery would be an in-kind sponsor of the sale.

A cross promotion is the term that is used for an event that is co-sponsored by more than one organization, or an organization and another type of sponsor, like a media outlet. It is called a cross promotion because the different organizations are each contributing something and are each benefiting from the association or partnership. An example of this might be when a local restaurant chain agrees to publicize a charity's fundraising event in its restaurants and has a booth set up at the event to serve food. The charity and the restaurant chain are co-sponsors and partners in the event. They both benefit, and working together they can make the event more successful than it would have been if only one of them sponsored it.

\section{PLANNING COMMITTEES}

Sometimes events, especially those that are conducted on behalf of charities or nonprofits, are coordinated by a planning or administrative committee. The key to success for a planning committee is having the right balance. The size of the committee may vary, but it will be most effective if the number of members is related to the complexity of the event. For large events with many types of coordination roles and responsibilities, the committee might split into smaller sub-committees, each charged with a specific task or set of tasks.

Planning committees benefit from having people with imagination, persistence, patience, and a sense of humor. Well-balanced committees are diverse, in terms of personalities, demographics, experience, and interests. A committee planning an event needs structure and organization, and it needs leadership. Often, if the event to be planned is an annual one, there will be leadership slots that are filled with new members each year. Assistant chairs of subcommittees may move up to subcommittee chairs, and then to leadership for the entire committee. Some planning committee tasks may include the following:

- Event coordination

- Accounting

- Communications

- Decorations

- Entertainment

- Facilities, equipment, and supplies

- Maintenance

- Marketing

- Security

- Signage and banners

- Transportation

- Vendors

- Membership

\section{PERMITS}

Permits allow you to conduct activities at your event that are regulated and for which you need permission, such as having a fireworks display or serving food to the public. Permits are issued by local, state, and federal government agencies. If you are holding an event in a public place, it is very likely that you will need to secure a permit. Permits provide legal permission to hold your event and to conduct activities on your site. Usually there will be a fee to obtain a permit. Here are some examples of types of permits and the local government departments that issue them:

- Bingo or lottery: lottery or gaming department

- Food handling: health department

- Occupancy: fire department

- Parking: transportation department

- Parks usage: parks department

- Pyrotechnics (fireworks): fire department

- Sales tax: tax collector's office

- Sign and banners: zoning department

- Street closing: transportation department

\section{BUDGET}

An event budget represents all of the income and expenses of the event. A budget is based on income and expenses you reasonably believe you can expect with the resources available. Setting up a budget for an event involves taking into consideration all the costs you anticipate and coming 
up with a bottom-line figure that falls within what has been allocated for the event. In addition to food costs or fees for a meeting room, other things to consider that may cost money include speaker's fees, printed materials, audio-visual equipment, prizes or raffle items, giveaways, decorations, lighting, costumes and props, publicity, invitations, and entertainment. In addition to the costs involved, a budget includes income or revenue that results from any part of the event. Income can include ticket sales, silent auctions, raffles, pledges or donations, direct sales, and gifts.

\section{Event-Day Coordination}

Now you are ready to execute the plan you have developed. Event-day coordination involves executing the event plan and making sure everything goes as planned. As coordinator, it is the event manager's job to be the point person responsible for the coordination of all activities. That could be as simple as arriving at the meeting room early and making sure officers are there and ready to give officer reports, or as complex as orchestrating the details for a crowd of attendees at a banquet. Event managers need to be good team leaders, good listeners, and good communicators. Other elements of event-day coordination include programming, atmosphere, and staffing.

\section{PROGRAMMING}

In addition to personal leadership qualities, successful event managers also rely on setting up a solid program or script to coordinate event timing and activities. A program usually includes titles for activities to be held, as well as days, times, and locations for everything that is planned to take place. For events that include performances and introductions, scripts often include everything that will be said and by whom, as well as sound effects, music cues, and special effects.

\section{ATMOSPHERE}

Every little detail contributes to the appropriate atmosphere for an event. At a conference or trade show, the location of the meeting rooms, how the chairs are set up, the type of speakers, handouts, and other materials, even what kind of food is served at the breaks, all contribute to what attendees will take away from their experience. Think about how you could add to the atmosphere of a meeting or school fundraiser. When considering atmosphere, try to involve all of your audience members' five senses:

- Sound: Design the sound system and sound effects that capture attention.
- Sight: Strong visual elements are needed (signs, video, symbols, logos).

- Touch: Textures of napkins and a printed program help in this area.

- Smell: Perfume and food odors add to any event, but avoid bad odors.

- Taste: For any food-focused event, food and drink are powerful atmosphere elements.

\section{STAFFING}

Who will be working at the event to handle registration, greet attendees, coordinate programming duties and serve food and drinks, if appropriate? Successful event managers make sure they know everyone who is on the team. They also make sure team members know their responsibilities and understand how to communicate with each other. If you are running an event, it is always important to thank your team for their hard work, and to give team members credit. For example, an organization's president coordinating a meeting might want to thank members for attending, and then acknowledge officers who helped set up the event.

\section{Event Evaluation}

Events that do not turn out as planned are sometimes due to chance - like an outdoor event being rained out by an unexpected thunderstorm. However, there are some common reasons why events fail:

- Unwillingness to try something new to update an event that has been held for many years

- Lack of creativity and innovation in developing the event so that attendees are engaged and not bored

- Lack of marketing and publicity for the event

- Poorly selected and trained personnel

- Not enough money to put on the event

- Poor timing

- Poor site conditions

All of these factors are typically related to decisions made by the event manager or other team members. Good evaluation of an event takes into account what cannot be helped or anticipated, while trying to identify areas that can be improved upon.

Evaluation is the process of determining how effective an event was. Having a measurable outcome as you begin the event planning process, so that you can compare it with the end result, is one way of conducting an evaluation. Evaluation is done to help understand what worked and 
what did not work, in order to learn from the experience and plan even better events in the future. You also want to know what impacts and outcomes an event had. Looking at how much money was raised or how many people attended is one part of evaluation, but by itself, it does not explain enough about how the different parts of the event contribute to this outcome. It also does not explain what people thought about the event, or how the team members who worked the event think they could improve it in future.

You can evaluate an event along the way or comprehensively at the end. Event managers might do an evaluation "in-house" - by themselves or with the help of others on the team, also known as a "self-evaluation" - or with the use of "monitors" who observe the event and provide feedback to the event manager. Evaluation may also use surveys of attendees.

Evaluation is done to improve future events. To evaluate an event, you must first decide what you want to know, and then come up with a set of questions to ask, such as the following:

- Did attendees enjoy the event?

- Were they made to feel welcome?

- What was the best part of the event?

- Who was the best speaker?

- Did they like the location?

- Did they get their "money's worth"?

- Was the event at a good time of year, month, week?

- Would they recommend the event to others?

From a self-evaluation, the event manager and team members evaluate themselves and how they think they did. Here are some personal questions an event manager may need to answer:

- Was I a good leader?

- Was the special event worth it?

- What parts of the job did I like or dislike?

- Was the event a success or failure?

- Which people did I work well with (and which people will I never work with again)?

- Do I want to manage another event?

- Did I keep complete notes and fill out the paperwork?

\section{References}

Allen, J. (2009). Event planning: The ultimate guide to successful meetings, corporate events, fundraising galas, conferences and conventions, incentives, and other special events ( $2^{\text {nd }}$ ed.). Mississauga, Ontario: John Wiley \& Sons Canada.

Craven, R.E., \& Golabowski, L.J. (2006). The complete idiot's guide to meeting \& event planning ( $2^{\text {nd }}$ ed.). New York, NY: Alpha Books.

Devney, D.C. (2001). Organizing special events and conferences: A practical guide for busy volunteers and staff. Sarasota, FL: Pineapple Press.

Jago, L., Veal, A.J., Allen, J., \& Harris, R. (2000). Events beyond 2000: Setting the agenda. http://utsescholarship. lib.uts.edu.au/dspace/handle/2100/430. Retrieved May 18, 2010. Sydney, Australia: Australian Centre for Event Management. 